\title{
Melanocytes in the Testes of Eupemphix nattereri (Anura, Leiuperidae): Histological, Stereological, and Ultrastructural Aspects
}

\author{
RODRIGO ZIERI, SEBASTIÃO ROBERTO TABOGA, \\ AND CLASSIUS DE OLIVEIRA*
}

São Paulo State University, Department of Biology, Institute of Biosciences, Literature and Exact Sciences, São José do Rio Preto, São Paulo, Brazil

\begin{abstract}
Ectothermic vertebrates have a well-developed system of melanincontaining cells, which localize in several organs and tissues and compose an extracutaneous pigmentary system. This research aimed at characterizing histological and ultrastructural patterns of pigmented cells in the testes of the anura Eupemphix nattereri (Steindachner, 1963), including the stereological and quantitative evaluation of this cell type in the gonads. Ten adult males were collected in Nova Itapirema, São Paulo, Brazil, and submitted to morphological studies with light and transmission electron microscopy. The testis presents a great number of large cells with many brown granules and long cytoplasmic processes. The pigmented cells found in the testis are structurally similar to melanocytes, characterized by large amounts of melanosomes. The cells may be in intimate contact with the same cell type, with myoid cells surrounded by a large amount of collagen fibers, Leydig cells, and next to fibroblasts. The distribution and amount of extracutaneous melanocytes is variable when other organs and membranes are analyzed, allowing the establishment of species-specific patterns for the extracutaneous pigmentary system. Anat Rec, 290:795-800, 2007. (c) 2007 Wiley-Liss, Inc.
\end{abstract}

Key words: melanocyte; melanosomes; extracutaneous pigmentary system; testes; anura

Ectothermic vertebrates have a well-developed system of melanin-containing cells, distributed in several organs (liver, spleen, lung, heart, thymus, and gonads) and tissues (meninges and connective tissue surrounding blood vessels) and composing an extracutaneous pigmentary system (Gallone et al., 2002).

Melanocyte-like cells, which derive from the neural crest (Sichel et al., 1997) and produce and store melanin inside spherical or ovoid structures called melanosomes (Agius and Roberts, 2003), have been observed in the epidermis and in several organs (Agius and Agbede, 1984; Zuasti et al., 1998; Oliveira and Zieri, 2005). These cells are large and irregular in shape, with a great amount of intensely pigmented cytoplasm, and may be seen under stereoscope microscopy. They can have star-like or punctiform morphology, due to the presence or absence of cytoplasmic processes, respectively (Oliveira and Zieri, 2005).
Melanomacrophage centers are usually found in hematopoietic organs of basal vertebrates (Agius, 1980; Agius and Agbede, 1984) and present different types of granules inside the cytoplasm, which can indicate differ-

Grant sponsor: Coordenação de Aperfeiçoamento de Pessoal de Nível Superior (CAPES); Grant sponsor: São Paulo State Research Foundation (FAPESP); Grant numbers: 02/08016-9 and 05/02919-5; Grant sponsor: The National Council of Scientific and Technological Development; Grant number: 301111/05-7.

*Correspondence to: Classius de Oliveira, São Paulo State University (UNESP), Department of Biology, Rua Cristóvão Colombo, 2265, Jardim Nazareth, CEP: 15054 000, São José do Rio Preto, São Paulo, Brazil. E-mail: classius@ibilce.unesp.br

Received 21 February 2006; Accepted 22 March 2007

DOI 10.1002/ar.20553

Published online 31 May 2007 in Wiley InterScience (www. interscience.wiley.com). 
ent chemical substances, such as melanin, hemosiderin, and lipofuscin, resulting from the endosomal-lysosomal digesting processes (Agius and Agbede, 1984; Herraez and Zapata, 1991).

In amphibians, pigmented cells appear in tegument and in lung as typical melanocytes and in spleen and liver as melanomacrophage centers (Zuasti et al., 1998). Melanomacrophages found in the liver of amphibians are also known as Kupffer cells (Sichel et al., 1997; Zuasti et al., 1998; Prelovsek and Bulog, 2003).

Melanocytes are characteristically distributed in organs and tissues, with species-specific patterns of occurrence, types, and amounts (Aoki et al., 1969; Geremia et al., 1984; Gopalakrishnakone, 1986; Cicero et al., 1989; Pederzoli and Trevisan, 1990; Trevisan et al., 1991; Zagal'skaia, 1994; Christiansen et al., 1996; Sichel et al., 1997; Akulenko, 1998; Zuasti et al., 1998; Rund et al., 1998; Barni et al., 1999, 2002; Johnson et al., 1999; Oliveira et al., 2002, 2003; Prelovisek and Bulog, 2003; Oliveira and Zieri, 2005). It has thus been proposed that patterns of extracutaneous pigmentary systems may be established for each species (Oliveira and Zieri, 2005).

Previous studies have described large amounts of melanocyte-like pigmented cells in the interstitial testicular tissue in Physalaemus fuscomaculatus (Aoki, 1969), Physalaemus cuvieri (Oliveira et al., 2002, 2003), and Eupemphix nattereri (Oliveira and Zieri, 2005), presenting a brief and gross morphologic description of these cell types. Further characterization of the cells would be of great interest. Testicular pigmentation has been used as an important phenotypical character in the taxonomy and phylogeny of Dendrobatidae (Grant et al., 2006).

A few recent studies have described the extracutaneous pigmentary system of anuran amphibians (P. cuvieri, Oliveira et al., 2002, 2003; P. fuscomaculatus, Aoki et al., 1969; E. nattereri, Oliveira and Zieri, 2005; Rana esculenta, Cicero et al., 1989; Sichel et al., 1997; Barni et al., 1999, 2002; Gallone et al., 2002; Rana ridibunda, Akulenko, 1998; Xenopus laevis, Sichel et al., 1997; Zuasti et al., 1998). The present study aimed at characterizing histological and ultrastructural patterns of pigmented cells in the testis of the anuran Eupemphix nattereri, including stereological and quantitative evaluation of this cell type in the gonads.

\section{MATERIALS AND METHODS}

Ten adult male Eupemphix nattereri (Anura, Leiuperidae) were collected at temporary ponds $\left(21^{\circ} 04^{\prime} 40^{\prime \prime} \mathrm{S}\right.$; $\left.49^{\circ} 32^{\prime} 23^{\prime \prime} \mathrm{W}\right)$ in Nova Itapirema, São Paulo, Brazil, between September and October of 2003, when they were in the reproductive activity period. In the laboratory, the individuals were anesthetized, killed, and submitted to morphological studies. Animal handling and experiments were done according to the ethical guidelines of the São Paulo State University (Unesp), following the Guide for Care and Use of Laboratory Animals.

All animals were weighed and dissected out by medium incision exposing the reproductive organs. After this procedure, the testes were removed and weighted, and immediately immersed in Karnovsky fixative solution (0.1 M Sörensën phosphate buffer $\mathrm{pH} 7.2$ containing $5 \%$ paraformaldehyde and $2.5 \%$ glutaraldehyde). The material was dehydrated in an alcohol gradient and embedded in historesin (Leica-historesin embedding kit). Sections of $2 \mu \mathrm{m}$ were stained with hematoxylin-eosin and observed under an Olympus BX60 microscope.

Samples for transmission electron microscopy observations were fixed for $2 \mathrm{hr}$ at $25^{\circ} \mathrm{C}$ in $3 \%$ glutaraldehyde and $0.25 \%$ tannic acid at $\mathrm{pH} 7.3$ in Millonig's buffer. After washing in the same buffer, the samples were postfixed for $1 \mathrm{hr}$ in $1 \%$ osmium tetroxide diluted in same buffer, dehydrated in acetone, and embedded in araldite resin (Cotta-Pereira et al., 1976). Ultrathin silver sections $(75 \mathrm{~nm})$ were obtained using a diamond knife and stained with $2 \%$ uranyl acetate for 20 minutes (Watson, 1958) and $2 \%$ lead citrate in $1 \mathrm{~N}$ sodium hydroxide solution (Venable and Coggeshall, 1965) for $8 \mathrm{~min}$, and examined under a Leo-Zeiss EM - 906 transmission electron microscope operating at $80 \mathrm{kV}$.

\section{Stereology Assays}

Ten histological fields for each animal were examined using an image analyzing system software (Image ProPlus, Media-Cybernetics, Inc.). Stereological analyses were performed with the Weibel's multipurpose graticulate with 120 points and 60 test lines (Weibel, 1978), to compare the relative proportion (relative volume) of pigmented cells. The absolute volume of these cells was determined by multiplying the relative volume values by the mean testes weight, based on the determination that $1 \mathrm{mg}$ of fresh tissue has a volume of approximately $1 \mathrm{~mm}^{3}$, according to Vilamaior et al. (2006).

To correlate the testicular melanocytes and the remaining variables (body weight, testes weight, percentage of interstitial cells, germinative cells, and other cells types in the testis), outliers were identified and the Shapiro-Wilk test was used to test for normality. The Pearson correlation coefficient for parametric data was used for analysis of the results.

\section{RESULTS}

Eupemphix nattereri have paired and ovoid testes, measuring around $4.82 \pm 0.78 \mathrm{~mm}$ length, obtained from right testes from 10 animals. They present marked pigmentation in the testicular capsule (Fig. 1A,B) and around the seminiferous tubules, intimately associated with interstitial cells (Fig. 1C,D) so that the gonads present a dark brown color.

This intense pigmentation is due to the presence, in the testes, of great numbers of large cells with many brown granules and long cytoplasmic processes distributed in both interstitial and capsular regions of the gonads (Fig. 1C,D). Cell borders could not be identified by histological examination, because the cells displayed a very high variation of irregular shapes.

Evaluation of the pigmented cells under transmission electron microscopy showed large irregular nuclei, conspicuous nucleoli, and condensed chromatin in the peripheral region (Fig. 2A). The cytoplasm showed numerous processes, with poorly developed organelles, and consisted mostly of electron-dense corpuscles containing melanin (Fig. 2B). The cytoplasmic region pigment granule-free present a few Golgi's cisternae (Fig. 2D,E), and in association with these pigment granules, a prominent cytoskeleton can be observed (Fig. 2C). Melanosomes 

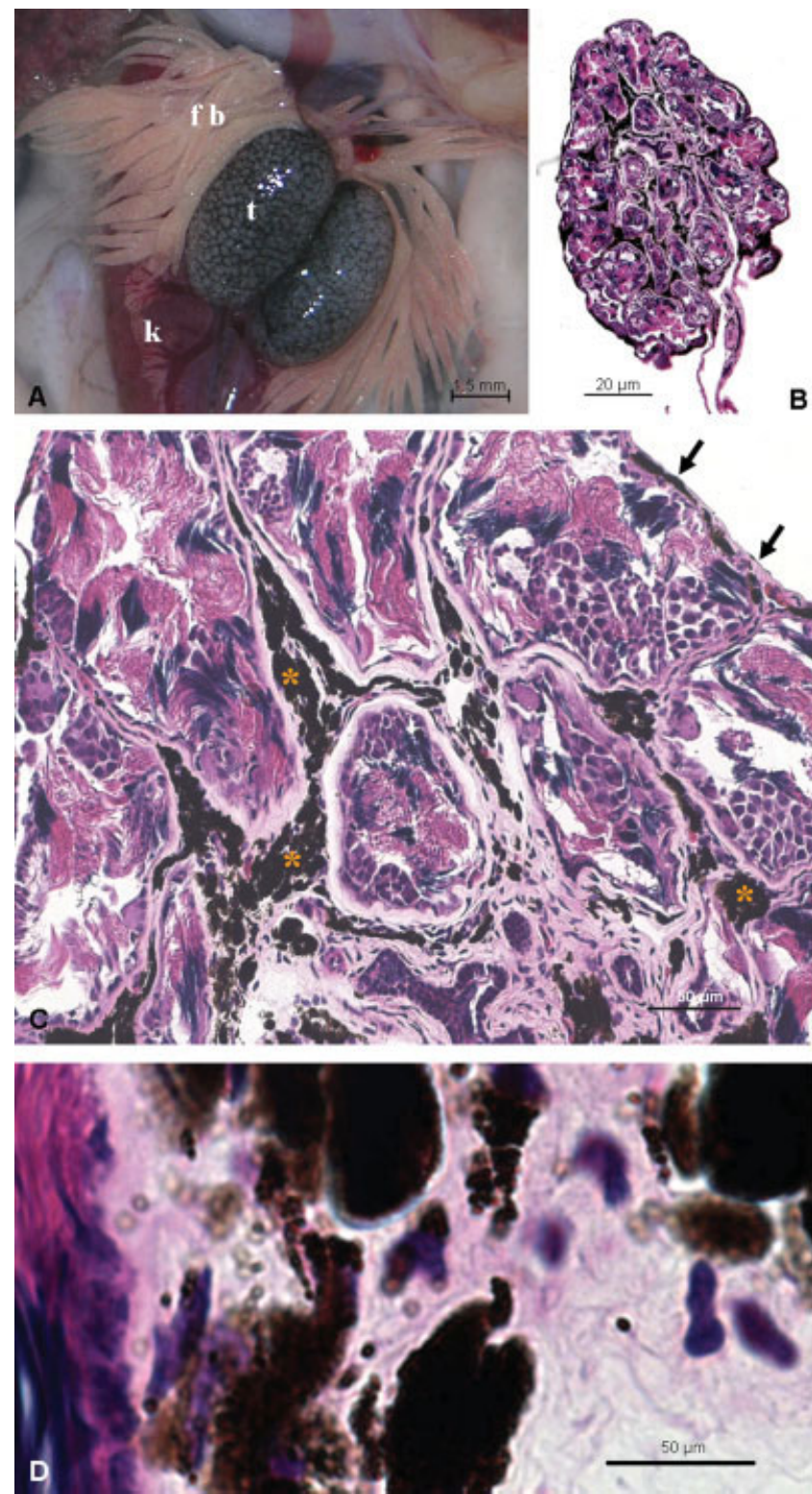

Fig. 1. A,B: Anatomical (A) and histological (B) general view of the testis of Eupemphix nattereri, showing intense pigmentation testicular. C: Pigmentation of the testicular capsule (arrows) and around the seminiferous tubules (asterisks). D: Detail of melanocytes in the testicular interstitium. fb, fatty body; t, testis; k, kidney.

presented round or ovoid shape with variable size and degree of melanization (Fig. 2F). The main characteristic of the mature pigmented cell in the testis evaluated in the present study is their homogeneous appearance and the presence of well-defined melanin granules (Fig. 2B).

The pigmented cells and their processes may be in intimate contact and/or high proximity with fibroblasts (Fig. 3A-C), with myoid cells surrounded by a large amount of collagen fibers (Fig. 3E,F), Leydig cells (not documented), and next to the same cell type, constituting a homotypic cell contact (Fig. 3D). Fibroblast and myoid cells were identified by ultrastructural analysis, using the evaluation of the basal membrane in the
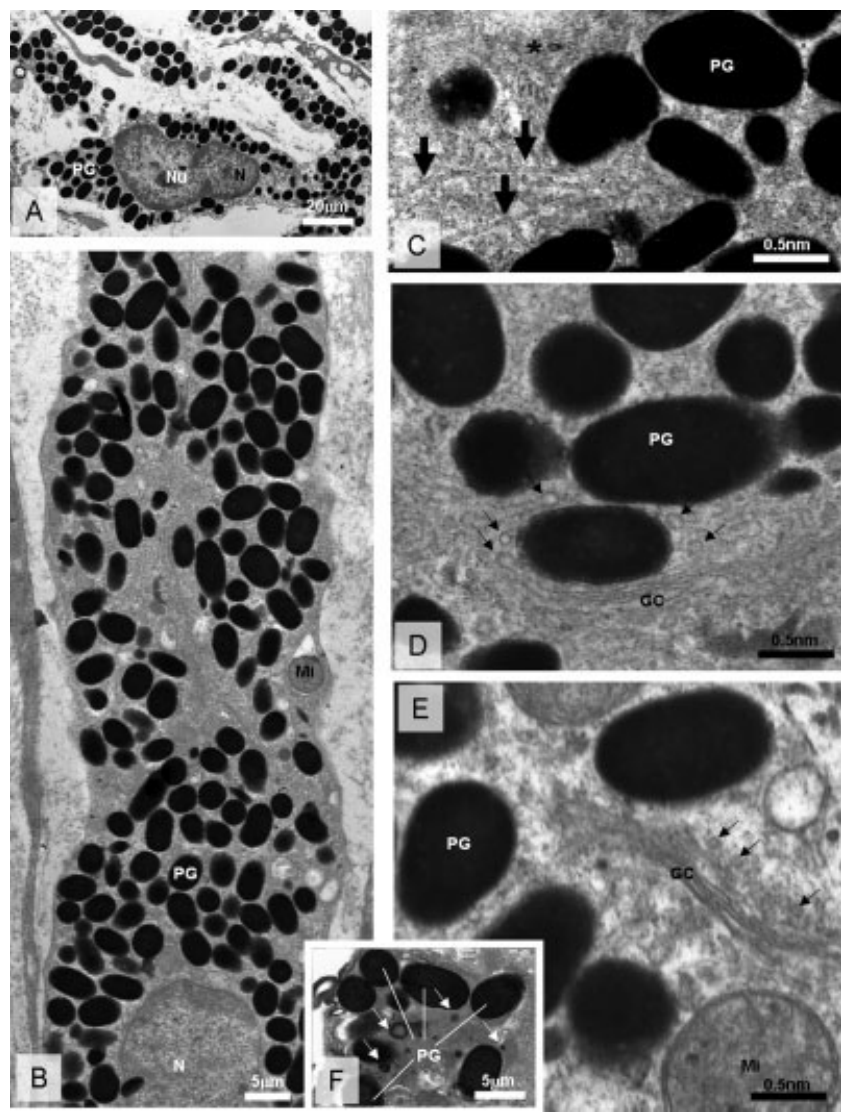

Fig. 2. Transmission electron microscopy of $E$. nattereri melanocytes. A,B: Melanocyte shows mature granules, with the cytoplasm full of melanosomes of different shapes, sizes, and electron densities. C: Detail of the melanocyte's cytoplasm showing cytoskeleton elements: microtubules (large arrows) and actin filaments (asterisk). D,E: Detail of melanocyte's cytoplasm demonstrating Golgi complex (GC) in association with secreting vesicles (small arrows). F: Cytoplasmic process of a melanocyte with melanosomes presenting different sizes and development stage (arrows). Mi, mitochondria; $\mathrm{N}$, nucleus; $\mathrm{Nu}$, nucleolus; PG, pigment granules.

myoid cells and absence of this structure in the fibroblast (Fig. 3F). Close contact, similar to focal adhesion, was also occasionally observed between fibroblasts, next to the pigmented cells (Fig. 3B).

Pigmented cells found in the testes are structurally similar to melanocytes, characterized by a large amount of melanin pigments in the interior of electron-dense corpuscles containing melanin, the melanosomes. The absence of the protein synthesis machinery organelles, such as granular endoplasmic reticulum, polysomes, and lysosomal-like vesicles or multivesicle bodies, typical of macrophages, were used here as evidence that this cell type is not a component of the melanomacrophage system.

Stereological analyses confirmed that most of the area in the testis $(58.06 \pm 9.53 \%)$ and the absolute volume $(8.12 \pm 1.33 \mathrm{mg})$ are occupied by germ cells and that melanocytes occupy $5.08 \pm 2.41 \%$ of the total area and $0.71 \pm 0.33 \mathrm{mg}$ of absolute volume. The melanocytes' absolute and relative volumes were not significantly correlated to body or testicular weight (Pearson correlation, 


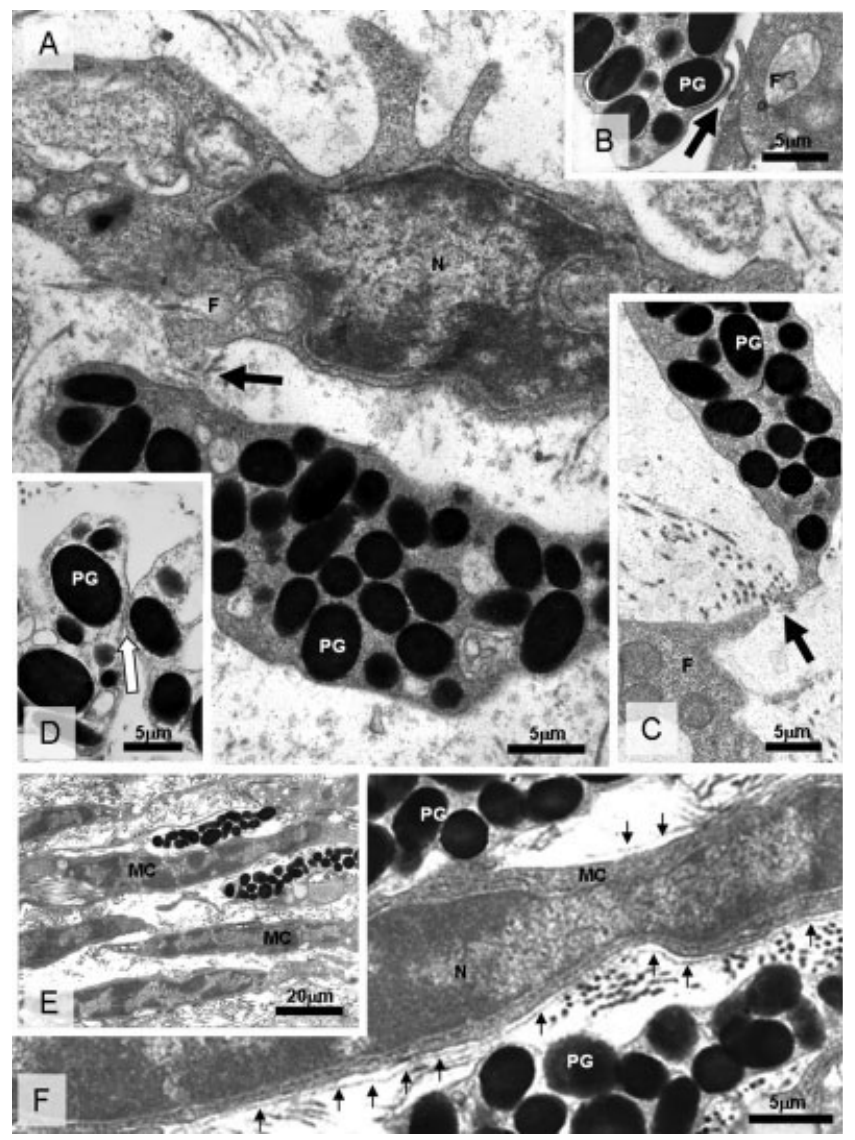

Fig. 3. Transmission electron microscopy of Eupemphix nattereri melanocytes. All figures demonstrate the association of this cell type with other cells, indicative of the cell communication. A-C: Proximity to fibroblast $(F)$ processes (dark arrows). D: Spot junction with plasmatic membrane of another melanocyte, characterizing a homotypical cell interaction (white arrow). E,F: Melanocytes closely associated to fibroblasts $(F)$, with collagen fibers around (Co) and myoid cells (MC) with the basal membrane (thin arrows). N, nucleus; PG, pigment granules.

$P \geq 0.05$ ), or to the volumetric values of interstitial and germinative cells. In addition, melanocytes volume showed negative correlation with the other testicular components (Pearson correlation, $r=-0.71 ; P=0.01$; Table 1).

\section{DISCUSSION}

Ectothermic animals have cells with pigmented cytoplasm, seen in different organs, which form the extracutaneous pigmentary system whose function is still poorly understood (Zuasti et al., 1998). The pigmented cells have different names, such as melanophores, melanocytes, melanomacrophages, melanin-containing mononuclear phagocytes, and melanophages. In amphibians (Sichel et al., 1997, Zuasti et al., 1998, Prelovisek and Bulog, 2003) and reptiles (Christiansen et al., 1996; Rund et al., 1998; Johnson et al., 1999), similar cell types present in the liver are called Kupffer cells.

These cells are morphologically similar to melanocytes (Agius, 1980; Zuasti et al., 1990, 1998) and macro-
TABLE 1. Quantitative Exploratory Analysis of the Testicular Components in Eupemphix nattereri ${ }^{a}$

\begin{tabular}{lr}
\hline \multicolumn{1}{c}{ Parameters } & \multicolumn{1}{c}{ Values } \\
\hline Biometrical data & \\
Body weight $(\mathrm{g})$ & $9.40 \pm 1.64$ \\
Testes weight $(\mathrm{g})$ & \\
Left & $0.013 \pm 0.01$ \\
Right & $0.015 \pm 0.01$
\end{tabular}

Stereological data

Relative volume (\%)

Melanocyte

Insterstitium

Germ cells

Other components

$5.08 \pm 2.41$

$11.33 \pm 5.51$

$58.06 \pm 9.53$

Absolute volume $\left(\mathrm{mm}^{3}\right)$

Melanocyte

Insterstitium

$25.51 \pm 13.54$

Germ cells

$0.71 \pm 0.33$

$1.58 \pm 0.77$

$8.12 \pm 1.33$

Other components

$3.57 \pm 1.89$

${ }^{\text {a Animal }}(\mathrm{n}=10)$; histological fields $(\mathrm{n}=10)$. Values represent mean $\pm \mathrm{SD}$.

phages. In ectothermic animals, macrophages have large amounts of melanin in the cytoplasm and are thus called melanomacrophages (Agius, 1980; Agius and Agbede, 1984; Macchi et al., 1992; Micale and Patti, 1993; Messeguer et al., 1994). Melanocytes originate from the neural crest, whereas melanomacrophages derive from hematopoietic stem cells (Sichel et al., 1997). According to the morphologic characteristics of the cells analyzed in testes and associated membranes in the present study, they were referred to as melanocytes.

The strong testicular pigmentation observed in E. nattereri is evidenced by cell types that are ultrastructurally similar to melanocytes. These cells are present in the skin (Trevisan et al., 1991) and in several visceras (Geremia et al., 1984), as well as in the testicular capsule and in close contact with interstitial cells, as described in P. fuscomaculatus (Aoki et al., 1969), Bombina bombina (Gollmann et al., 1993), P. cuvieri (Oliveira et al., 2002, 2003), and E. nattereri (Oliveira and Zieri, 2005).

Melanocytes are large irregular cells, with poorly developed organelles, a great number of melanosomes, and long dendritic processes with abundance of cytoskeleton, such as microtubules and actin filaments (Aoki et al., 1969). In E. nattereri testes, melanocytes have melanosomes of different sizes and degrees of melanization, suggesting the occurrence of melanogenic activity as described by Sichel et al. (1997) and Gallone et al. (2002) in Rana esculenta. The melanogenesis in E. nattereri testes is suggested here due the presence of the several Golgi's cisterns in association with secreting vesicles. But the confirmation of this process will certainly be a new focus of further investigations in our research group.

Melanosynthesis has also been observed in Kupffer cells in amphibian liver (Cicero et al., 1989; Sichel et al., 1997), as shown by the presence of premelanosomes in several stages of differentiation and by the activity of dopa-oxidase in $R$. esculenta (Gallone et al., 2002) and Proteus anguinos (Prelovsek and Bulog, 2003). Melanosynthesis, however, has not been observed in melanomacrophages of some species of fish, showing that the melanin 
inside the cells derives from phagocytosis of melanosomes originating from melanocytes (Agius and Agbede, 1984; Tsujii and Seno, 1990; Zuasti et al., 1990; Herraez and Zapata, 1991).

In teleosts, Besseau and Faliex (1994) and Grier and Taylor (1998) have described the presence of melanomacrophages in testicular structures and that they might be involved with the gonadal regression observed after maturation of germinative cells. In E. nattereri, melanomacrophages have not been observed in the testicular interstitium. The cells could, however, be present in low density or only in specific phases of the reproductive cycle or yet in response to infectious processes, when they could then be identified. In anurans and teleosts, these cells are clearly evident in hematopoietic organs such as the liver and spleen (Cicero et al., 1989; Zuasti et al., 1990; Sichel et al., 1997) and in the kidneys (Zuasti et al., 1989).

Functions of the melanin inside melanomacrophages include a possible role in the absorption and neutralization of free radicals, cations, and other potentially toxic agents derived from the degradation of phagocytosed cells (Zuasti et al., 1989), as well as in the thermoregulation process in reptiles (Golapakrishnakone, 1986). Barni et al. (1999) reported an increase of melanic cells in the liver of $R$. esculenta during winter. In $E$. nattereri the function of these pigmented cells yet cannot be completely explained, but the evidence of the thermoregulation role may be indicated here. However, this hypothesis will be tested in further experimental assays.

The cells are structurally very similar when compared in other species such as B. bombina (Gollmann et al., 1993) and $P$. cuvieri (Oliveira et al., 2002, 2003). However, the distribution and amount of extracutaneous melanocytes is variable when other organs and membranes are analyzed, allowing the establishment of species-specific patterns for the extracutaneous pigmentary system (Oliveira and Zieri, 2005).

The present study describes characteristics that can be further explored in the characterization of anurans, providing morphological results of importance for the use of other approaches involving physiological and phylogenetic aspects. The anuran extracutaneous pigmentary system has been a target of research in our laboratory with emphasis on reproductive organs, and other complementary immunocytochemical and enzymological methodologies have been established. In this sense, major information about the physiology of these cells will be incorporated to the literature in future.

\section{ACKNOWLEDGMENTS}

This study is part of Master's thesis presented by R.Z. to the Animal Biology Post-graduation Course, Ibilce/ Unesp. The authors thank Luiz Roberto Falleiros Júnior and Rosana Silistino de Souza for technical assistance. R.Z. received a fellowship from the Coordenação de Aperfeiçoamento de Pessoal de Nível Superior. S.R.T. thanks the National Council of Scientific and Technological Development.

\section{LITERATURE CITED}

Agius C. 1980. Phylogenetic development of melano-macrophage centres in fish. J Zool 191:11-31.
Agius C, Agbede SA. 1984. An electron microscopical study on the genesis of lipofuscin, melanin and haemosiderin in the haemopoietic tissues of fish. J Fish Biol 24:471-488.

Agius C, Roberts RJ. 2003. Review: melano-macrophage centres and their role in fish pathology. J Fish Biol 26:499-509.

Akulenko NM. 1998. Topography and structure of the pigment cell aggregation in the liver of the frog (Rana ridibunda). Vest Zool 32:49-53.

Aoki A, Vitale-Calpe R, Pisano A. 1969. The testicular interstitial tissue of the amphibian Physalaemus fuscomaculatus. Z Zellforsch Mikrosk Anat 98:9-16.

Barni S, Bertone V, Croce AC, Bottiroli G, Bernini F, Gerzeli G. 1999. Increase in liver pigmentation during natural hibernation in some amphibians. J Anat 195:19-25.

Barni S, Vaccarone R, Bertone V, Fraschini A, Bernini F, Fenoglio C. 2002. Mechanisms of changes to the liver pigmentary component during the annual cycle (activity and hibernation) of Rana esculenta L. J Anat 200:185-194.

Besseau L, Faliex E. 1994. Resorption of unemitted gametes in Lithognathus mormyrus (Sparidae, Teleostei): a possible synergic action of somatic and immune cells. Cell Tissue Res 276:123132.

Cicero R, Mallardi A, Maida I, Gallone A, Pintucci G. 1989. Melanogenesis in the pigment cells of Rana esculenta L. liver: evidence for tyrosinase like activity in the melanosome protein fraction. Pigment Cell Res 2:100-108.

Cotta-Pereira G, Rodrigo FG, David-Ferreira JF. 1976. The use of tannic acid-glutaraldehyde um the study of elastic related fibers. Stain Technol 51:7-11.

Christiansen JL, Grzybowski JM, Kodama RM. 1996. Melanomacrophage aggregations and their age relationships in the yellow mud turtle, Kinosternon flavescens (Kinosternidae). Pigment Cell Res 9:185-190.

Gallone A, Guida G, Maida I, Cicero R. 2002. Spleen and liver pigmented macrophages of Rana esculenta L. A new melanogenic system? Pigment Cell Res 15:32-40.

Geremia E, Corsaro C, Bonomo R, Giardinelli R, Pappalardo P, Vanella A, Sichel G. 1984. Eumelanins as free radicals trap and superoxide dismutase activities in Amphibia. Comp Biochem Physiol 79:67-69.

Gollmann G, Borkin LJ, Roth P. 1993. Genic and morphological variation in the fire-bellied toad, Bombina bombina (Anura, Discoglossidae). Zool Jahrb Abt Syst Oekol Geogr Tiere 120:129136.

Gopalakrishnakone P. 1986. The structure of the pigment cells in the turtle Trionyx sinensis. Arch Histol Jpn 49:421-435.

Grant T, Frost DR. Caldwell JP, Gagliardo R, Haddad CFB, Kok PJR, Means DB, Noonan BP, Schargel WE, Wheeler WC. 2006. Phylogenetic systematics of dart-poison frogs and their relatives (Amphibia: Athesphatanura: Dendrobatidae). Bull Am Mus Nat Hist 299:262.

Grier HJ, Taylor RG, 1998. Testicular maturation and regression in the common snook. J Fish Biol 53:521-542.

Herraez MP, Zapata AG. 1991. Structural characterization of the melanomacrophage centres (MMC) of goldfish Carassius aurata. Eur J Morphol 29:89-102.

Johnson JC, Schwiesow T, Ekwall AK, Christiansen JL. 1999. Reptilian melanomacrophages function under conditions of hypothermia: observations on phagocytic behavior. Pigment Cell Res 12:376-382.

Macchi GJ, Romano LA, Christiansen HE. 1992. Melano-macrophage centres in whitemouth croaker, Micropogonias furnieri, as biological indicators of environmental changes. J Fish Biol 40: 971-973.

Messeguer J, López-Ruiz A, Esteban MA. 1994. Melano-macrophages of the seawater teleosts, sea bass (Dicentrachus labrax) and gilthead seabream (Sparus aurata): morphology, formation and possible function. Cell Tissue Res 277:1-10.

Micale V, Patti F. 1993. Melanomacrophage centres in the spleen of seabass, Dicentrachus labrax L., and gilthead seabream, Sparus aurata L., during their reproductive cycle. Eur Arch Biol 104:9398. 
Oliveira C, Zieri R. 2005. Pigmentação testicular no anfíbio Physa laemus nattereri (Anura): observações anatômicas sobre o sistema pigmentar extracutâneo. Rev Bras Zool 22:454-460.

Oliveira C, Zanetoni C, Zieri R. 2002. Morphological observations on the testes of Physalaemus cuvieri (Amphibia, Anura). Rev Chil Anat 20:263-268.

Oliveira C, Sant'anna AC, Omena PM, Santos LRS, Zieri R. 2003. Morphological considerations on the seminiferous structures and testes of anuran amphibians: Bufo crucifer, Physalaemus cuvieri and Scinax fuscovarius. Biociencias 11:39-46.

Pederzoli A, Trevisan P. 1990. Pigmentary system of the adult alpine Salamander atra aurorae. Pigment Cell Res 3:80-89.

Prelovsek P, Bulog B. 2003. Biogenesis of melanosomes in Kupffer cells of Proteus anguinus (Urodela, Amphibia). Pigment Cell Res $16: 345-350$

Rund CR, Christiansen JL, Johnson JC. 1998. In vitro culture of melanomacrophages from the spleen and liver of turtles: comments on melanomacrophage morphology. Pigment Cell Res 11:114-119.

Sichel G, Scalia M, Mondio F, Corsaro C. 1997. The amphibian Kupffer cells build and demolish melanosomes: an ultrastructural point of view. Pigment Cell Res 10:271-287.

Trevisan P, Pederzoli A, Barozzi G. 1991. Pigmentary system of the adults alpine salamander Salamandra atra atra. Pigment Cell Res 4:151-157.
Tsujii T, Seno S. 1990. Melano-macrophage centres in the aglomerular kidney of the sea horse (teleosts): morphologic studies on its formation and possible function. Anat Rec 226:460-470.

Venable JH, Coggeshall R. 1965. A simplified lead citrate stain for use in electron microscopy. J Cell Biol 25:407-408.

Vilamaior PSL, Taboga SR, Carvalho HF. 2006. The postnatal growth of the rat ventral prostate in Wistar rats: a stereological and morphometrical study. Anat Rec 288A:885-892.

Watson ML. 1958. Staining tissue sections of electron microscopy with heavy metals. J Biophys Biochem Cytol 4:475-478.

Weibel ER. 1978. Principles and methods for the morphometric study of the lung and other organs. Lab Invest 12:131-155.

Zagal'skaia EO. 1994. The vascular melanocytes of the pia mater and mesentery of the small intestine in the frog: structure and functions. Tsitologiya 36:796-801.

Zuasti A, Jarra JR, Ferrer C, Solano F. 1989. Ocurrence of melanin granules and melanossynthesis in the kidney of Sparus auratus. Pigment Cell Res 2:93-100.

Zuasti A, Ferrer C, Aroca P, Solano F. 1990. Distribution of extracutaneous melanin pigment in Sparus auratus, Mugil cephalus and Dicetrachus labrax (Pisces, Teleostei). Pigment Cell Res 3:126131.

Zuasti A, Jiménez-Cervantes C, García-Borrón JC, Ferrer C. 1998. The melanogenic system of Xenopus laevis. Arch Histol Cytol 61:305-316. 